\title{
Worlding infrastructure in the global South: Philippine experiments and the art of being 'smart'
}

(c) Urban Studies Journal Limited 2020

Article reuse guidelines: sagepub.com/journals-permissions DOI: I0.1 I77/004209801989I0I I journals.sagepub.com/home/usj

@SAGE

\section{Morgan Mouton}

University of Calgary, Canada

\begin{abstract}
This article explores the material dimensions of 'smart city' initiatives in the context of postcolonial cities where urban utilities are qualified as deficient. It argues that while such projects may very well be another manifestation of urban entrepreneurialism, they should not be dismissed as an already-outdated research object. Rather, they can be analysed in light of postcolonial cities' development agenda. Here, I document and analyse the ongoing construction of New Clark City, a smart city project that is envisioned by the current Philippine state administration as a solution to the crisis that Metro Manila's urban infrastructure is going through. In doing so, I seek to integrate Science and Technology Studies' insights on infrastructure provision with the literature on worlding efforts in cities of the global South.
\end{abstract}

\section{Keywords}

infrastructure provision, Mega-Manila, provincialising, smart city, splintering urbanism, worlding

\section{摘要}

本文探讨后殖民城市背景下 “智慧城市” 倡议的物质层面，在后殖民城市中，城市公用 事业被定性为不足。本文认为，尽管这些项目很可能是城市创业精神的另一种表现形式， 但它们不应被视为已经过时的研究对象。相反, 我们可以根据后殖民城市的发展议程来 分析它们。在本文中, 我描述并分析了正在进行中的新克拉克市 (New Clark City) 的建设。 这是一个智慧城市项目, 被现任菲律宾政府设想为解决大马尼拉城市基础设施正在经历 的危机的方案。藉此, 我寻求将科学技术研究对基础设施建设的见解与全球南方城市的 世界化 (worlding) 努力方面的文献进行整合。

关键词

基础设施供应、大马尼拉、行省化、智慧城市、分裂的城市化、世界化

Received January 2019; accepted November 2019

\section{Introduction}

'Manila, I think will be, in about 25 years, will be a dead city. It will start to decay', proclaimed Rodrigo Duterte in a speech

\section{Corresponding author:}

Morgan Mouton, Department of Community Health Sciences, Cumming School of Medicine, University of Calgary, Teaching, Research and Wellness Building (3rd floor), 3280 Hospital Drive NW, Calgary, AB, T2N 4Z6, Canada.

Email: morgan.mouton@ucalgary.ca 
aimed at supporting the development of a 'smart city' on a 9450-hectare tract of land in the north-east of the Philippine capital city (Rappler, 2017a). In this speech, the president of the Republic of the Philippines argues that Metro Manila's infrastructure is hopeless and beyond repair or improvement, calling instead for a decentralisation of its activities. 'You cannot rehabilitate the place, you have to baklasin mo ang Maynila [break Manila apart] to do that', he adds ${ }^{1}$ (Rappler, 2017a). The assertive tone is characteristic of Duterte, who does not expand on how he envisions moving the 13 million inhabitants currently living in the Philippines' largest metropolis into a presently empty tract of land. While some would quickly discard this statement, on account of the President of the Philippines routinely resorting to similar angry outbursts and shocking announcements, I suggest that this speech is worthy of consideration. It reveals how critical the situation of Metro Manila's infrastructure is perceived to be, and how new, preferably 'smart', developments such as Clark are presented as a comprehensive solution to the problem. Strikingly, it is the newness of the smart city that seems to be appealing for Duterte: the project is not about improving an already-existing built environment and enhancing it with new technologies, but rather planning and constructing something entirely novel, integrated and devoid of past mistakes.

The present special issue seeks to adopt a global, non-Western-centric approach for the study of the myriad of projects branding themselves as smart cities. Acknowledging the diversity of smart city initiatives around the world, it follows a narrow ridge that overlooks two strands of smart city scholarship: (1) studies that point to the need to provincialise the literature and place more focus on projects that are not initiated by major state or corporate actors, but rather emerge from the periphery, and hold the potential to destabilise dominant forms of organisation in urban areas; and (2) studies that critically analyse how smart initiatives have become a way for cities to gain substantial national and international visibility, and therefore attract investors.

In this article, I argue that considering what Harris (2013) calls concrete geographies, and placing the focus on the material dimension of smart cities, can help advance such a research agenda. I am proposing to unpack the project of New Clark City (NCC), a development located north of the Philippine capital region, by examining its provision of urban services. Following scholars who have expressed similar calls for more attention to networked infrastructure provision in urban studies (Gandy, 2005; Graham and Marvin, 2001; Lorrain, 2014; McFarlane and Rutherford, 2008), not least using a Science and Technology Studies perspective (Coutard and Guy, 2007), I argue that this lens is especially relevant for the study of smart city initiatives in the global South. I show how infrastructure provision is a critical aspect of NCC, in that it is simultaneously presented by its proponents as a condition for, and also a marker of, economic development. With this in mind, I contend that unpacking infrastructure provision can be a heuristic for studying smart city projects. The circulation of technologies and expertise behind networked infrastructure highlights the regional and global dimension of NCC. Consequently, looking at infrastructure provision also contributes to scholarship on worlding cities (Roy, 2011; Roy and Ong, 2011). Meanwhile, unpacking the practicalities of infrastructure provision in NCC is also a way to ground the study, and explore the Philippine political economy of urban production. Unfolding the stories behind the pipes and cables that are being laid under NCC prompts encounters with the local actors involved in the financing, planning and construction of the project. 
This approach also leaves room for local contingencies to be examined and analysed in a word, it also echoes the injunctions to provincialise our understanding of the production of smart urbanism.

Methodologically, such an approach relies on a careful documentation of the project, through a monitoring of public-domain publications (press releases concerning the project, calls for public biddings and notices of awards detailing the planned infrastructure) and media coverage around the project. In obtaining the lay of the land for the project, one can start to identify the actors involved in its development. The next step is therefore to accumulate more data on these actors - in this case, the public agency spearheading the project, the Bases Conversion and Development Authority (BCDA), but also the myriad of technology companies, utilities and real-estate developers involved. Again, a monitoring of the economic press was valuable for this endeavour, but key information was also found in these companies' annual reports and filings. Lastly, these data were also complemented by in-depth interviews carried out with six executives from the BCDA, the agency in charge of developing NCC. More generally, this research built upon extensive fieldwork (approximately 12 months over three stays) carried out in Metro Manila between 2014 and 2017, during which I was able to gain insight on some of the underpinnings of the political economy of urban production in the Philippines.

The first section of this article will make a case for highlighting infrastructure provision when it comes to understanding smart city initiatives. More specifically, it will replace such projects in the context of cities that are faced with major challenges with regards to service provision, but also where urban elites seek to demonstrate their modernity through a showcasing of technological know-how. From there, the second and third sections will use $\mathrm{NCC}$ as a case in point. In the second section, I will show how studying planned infrastructure for NCC helps shed light on the social, economic and political objectives of this smart city initiative. More specifically, I will show how, and the extent to which, NCC can be characterised as a utopian project - and with which consequences for the MegaManila region. In the third section, I will consider the political economy of infrastructure production, and will discuss the relevance of the worlding cities grid of analysis for the case of NCC, thus questioning and characterising the global - and regional - dimensions of the project.

\section{Smart cities as infrastructure}

Projects that are branded as smart city initiatives can be very diverse in nature and in scale, but they usually share the common trait of being heavily publicised and aggressively promoted by their instigators. It assuredly has to do with the considerable levels of investment that public authorities and corporate interests pour into such projects, but beyond that, Wiig (2015) summarises the situation well when he posits that 'smart city efforts are best understood as examples of outward-looking policy promotion for the globalised economy'. He makes a strong case for considering smart city projects as part of the toolbox that urban elites use to world their cities. In this section, I would like to refine this idea by stressing that part of the appeal that such initiatives have in cities of the global South derives from their infrastructural nature and the role they play in branding and entrepreneurialism.

When working on smart cities, setting the contours of the object of analysis is challenging because of the polysemy of the term, and its abundant use by a very wide variety of scholars and practitioners (Hollands, 2008). Before going further, it is sensible, 
then, to clarify the posture adopted in this article, and defend the idea that such projects can usefully be defined by their focus on infrastructure for the purpose of this analysis. Kitchin (2014) distinguishes two broad understandings of smart cities. The first one refers to the increasing ubiquity of sensors and computing devices within the urban fabric - what Picon (2015: 28) more lyrically describes as cities becoming able to 'learn, understand and reason'. Ultimately, the assumption is that the proliferation of such devices will allow for unprecedented knowledge of the city, and therefore increase its controllability while enhancing the efficiency of service delivery, and, hopefully, improve its sustainability. The second view on smart cities adopts a broader perspective that refers to an economic policy rather than to an evolution in technologies. Hollands (2008) underlines that practitioners' understanding of smart cities cannot be reduced to a digitisation of urban infrastructure. Here, Information and Communication Technologies (ICTs) are rather seen as a tool for attracting and connecting smart people in order to foster the development of a knowledge economy characterised by innovation, creativity and entrepreneurship - in a sense, to attract the creative class that Florida (2004) depicted before the smart city became in vogue.

For the purpose of this article, I would like to call for a conceptualisation of smart cities as infrastructure. To be clear, such a stance does not imply that only the material dimension of smart cities be taken into account. Rather, I borrow Picon's (2017, 2018) understanding of infrastructure as a set of three, mutually interacting components: a material basis, a set of stabilised socio-technical practices and what he terms imagination (i.e. a set of representations and values shared by a multiplicity of stakeholders: engineers, maintenance technicians, political leaders, as well as end-users). As a consequence, the digitisation of cities cannot merely be reduced to the installation of sensors and to the production of data. Smart urbanism also implies the development of new practices, new standards and norms, as well as the conjuration of new ideals and urban models. This conceptualisation of infrastructure can be helpful in navigating through the complexities of urbanism. Following pipes and cables can shed a new light on smart city initiatives. It calls for our attention to move beyond flagship projects, and towards an examination of the more mundane aspects of city-building. One only needs to witness a power cut, an interruption in water distribution or a halt in rubbish collection in order to realise its essential character. Studying service delivery, its priorities how it may favour certain areas over others, for instance - but also how it is planned and managed, gives precious insights into the governance of a city. The financing of infrastructure - for example, directly, or through various forms of public-private partnerships (PPPs) - the diverse modalities of delegation to utilities and the oversight exercised by public authorities are many elements that can inform us of the constraints faced by cities, and of the objectives pursued by their elites (Le Galès and Lorrain, 2003; Lorrain, 2014).

Vanolo (2014: 883) appositely argues that 'the smart city discourse distances urban government from politics and represents the urban question in terms of the environment and technology, broadening the field of action of technicians, consultants and private companies'. Focusing on the infrastructural dimension of smart cities is precisely a way to avoid falling into this trap, provided that one acknowledges, and brings out, the intrinsically political nature of infrastructure. A contribution from Science and Technology Studies (STS) is to show how infrastructure projects reflect the balance of power of the organisations involved in their development (e.g. Pritchard, 2011). They are 
a product of different political agendas, which are integrated into their very materiality - it is what Gabrielle Hecht (2014) termed technopolitics (see also Edwards and Hecht, 2010; Jaglin and Dubresson, 2016). Take for instance the well-known example of how Robert Moses built low-clearance tunnels that could not accommodate buses, in order to restrict access to Long Island beaches for less-affluent New Yorkers (Rowland and Passoth, 2015). Accordingly, placing the focus on the infrastructure of smart cities can be viewed as a methodological stance. It forces us to consider the less visible, yet crucial aspects of urban production. In this sense, this approach also represents an answer to the call for the study of 'actually existing smart cities' (Shelton et al., 2015).

\section{Focusing on infrastructure to characterise smart cities' raison d'être}

I have argued that focusing on infrastructure provision is a helpful way to better understand smart city projects. In this section, I would like to operationalise this idea by presenting the case study of NCC. First, I will show that studying the infrastructural components of NCC can help shed light on its objectives - namely, to showcase development in the context of an urbanisation often depicted as haphazard and suboptimal (Navarro, 2016). Second, I will highlight how these objectives entail a territorial and infrastructural rupture with the surrounding Mega-Manila region.

\section{Showcasing Philippine 'development'}

If infrastructure constitutes a relevant point of entry for the study of smart cities generally, it is especially so in countries of the global South. I would indeed like to argue that their infrastructural dimension constitutes a powerful driver for smart city initiatives and related policies. As noted in the context of sub-Saharan Africa (Watson, 2014) or of India (Datta, 2015), the 'smart city rhetoric' is closely intertwined with an agenda of development. And infrastructure tends to be associated with a 'sense of shaping modern society and realising the future' (Larkin, 2013: 332) - they arguably constitute the very underpinning of modernity. In fact, a dual dynamic is at play. On the one hand, infrastructure is envisioned as a demonstration, or an indicator, of development. On the other hand, infrastructure is also conceived as a medium for development and competitiveness - a belief that Marshall (2012) designates by infrastructuralism.

The same is true for the Philippines, especially as the context of Metro Manila is indeed one of infrastructural crisis. The megacity's demography is impressive: from a city of 623,000 inhabitants in 1939, according to that year's census (Caoili, 1989: 52), it became a metropolis of 13 million inhabitants today, with projections estimating that the population could reach 19 million in the coming years (Porio, 2014: 80). Urban services did not catch up, however, and service delivery is now perceived as a major obstacle towards higher economic growth (ADB, 2013; World Bank, 2005). An obvious example is the traffic congestion that cripples the city (Boquet, 2013): in 2015, the secretary for economic planning estimated that road congestion engenders a loss of 3 billion pesos (US\$64 million) every day in Metro Manila (Philippine Star, 2015). Other services are, however, equally important: electricity provision is vulnerable and has failed in the past (Mouton, 2015), and while the two water utilities that cover the metropolitan territory have significantly improved their coverage in terms of water distribution over the past three decades, a pressing issue is the treatment of wastewater, which currently infiltrates groundwater (World Bank, 2010). 
In this context, it is striking to note that NCC is part of a huge infrastructural push initiated in the beginning of the 2010s, and amplified further by president Duterte's 'build-build-build' programme. Duterte is best known, abroad, for his derogatory language and his alleged violations of human rights (Human Rights Watch, 2018), but another important topic in his communication strategy is the modernisation of the country's infrastructure (Forbes, 2018). The programme is massive in scale: 75 projects $^{2}$ ranging from highways to new airports and energy plants, and representing a projected spending of US\$180 billion by 2022 (Alegado, 2018). The pace is also noteworthy: the projects are fast-tracked, consistently with Datta's (2016) observation that speed is an important dimension of projects envisioned as a solution to the 'urban crisis'.

Building a new city in the north of Manila therefore has to be understood as fulfilling two objectives. First, as reflected in the statement presented at the beginning of the article, the idea is to alleviate the pressure on the national capital region by relocating government and business activities. Second, and perhaps more importantly, the new city has to be 'smart' in order to show the world that the urban Philippines is not characterised by the infrastructure breakdowns and haphazard service provision that cities of the global South tend to be associated with (McFarlane, 2010; Silver, 2016). As Datta (2018: 407) puts it: 'Smart cities can no longer be cast solely as the mobility of global visions of urban futures, rather as the extension of state aspirations of governmentality, modernity and the control of "disorder" into a digital urban age.'

NCC is indeed expected to boast new - and supposedly environmentally friendly - technologies that can demonstrate the Philippines' improving situation, from the 'sick man of Asia' (Kind, 2000) to an emerging regional economy. Located $100 \mathrm{~km}$ north of Metro
Manila (see Figure 1), NCC is a massive project with regards to its size ( 9450 hectares) and the level of investments involved, which amount to over US\$14 billion (Business Insider, 2018). By the time of its completion, in 25-30 years, it is envisioned to host 1.2 million inhabitants.

The project took off under the presidency of Benigno Aquino III, who carried out an official ground-breaking ceremony in April 2016. It was, however, fast-tracked by his successor, Rodrigo Duterte, who changed its name along the way from Clark Green City to New Clark City. It sits on a former US military base that the Philippines recovered in 1991, and as such it is managed by the BCDA. It is comprised of a mixed-use core of 288 hectares that includes office buildings, residential units and an industrial estate, but also a National Government Administrative Center modelled after Putrajaya (Malaysia) that will host several national administrations, as well as a sports complex that will host the Southeast Asian Games in December 2019. In addition, procurement is under way for the construction of an agroindustrial hub, the Food Processing Terminal and International Food Market.

The project is ambitious, and framed as a new frontier in terms of urbanism: 'New Clark City is being conceptualised to be the country's largest and first, smart, green and disaster-resilient city', reads a report by the main real-estate developer, Filinvest (Filinvest Development Corporation, 2017: 10). Features include the creation of a centralised and integrated system for utilities (energy, water and sewerage, telecommunications), controlled from an 'operations centre'. Also in line with the imaginaries of the control room, NCC will have a 'Disaster Risk and Recovery Centre' aiming at increasing the resilience of this region of high seismic activity, which also suffered direly from the 1991 eruption of Mount Pinatubo - the second largest volcanic eruption of the 20th century. 


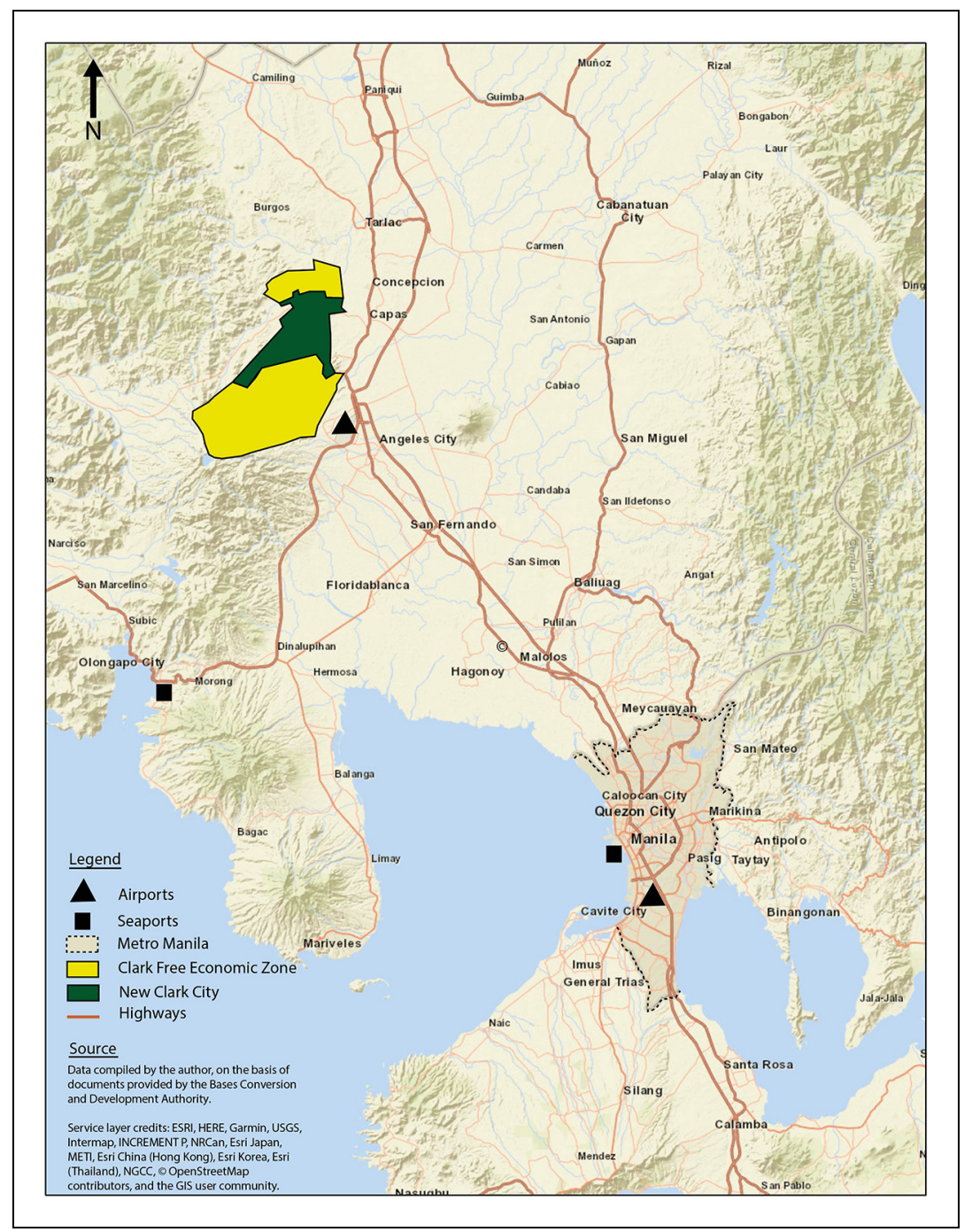

Figure I. New Clark City and the decongestion of Metro Manila. Connecting the Philippine national capital region to its 'smart city'.

Source: Base map obtained from OpenStreetMap; cartographic work by the author.

Environmentally, the city is also envisioned to include several advanced features, such as a district cooling system and an energy management and storage system. The idea of sourcing its electricity from sustainable sources (geothermal, wind and photovoltaic) is also being discussed, although the realisation of this objective is not detailed in the plans already available to the public. ${ }^{3}$ The question of mobility within the city is also heavily discussed, with the objective of promoting walking and cycling - in sharp contrast with most Philippine cities, where walking can be a frustrating, sometimes dangerous, experience and cycling is marginal, to say the least, given the lack of adequate infrastructure. 
There is an already well-established critique of the elitist and exclusionary nature that characterises most of the projects that advertise themselves as 'smart' (Hollands, 2008, 2015; Marvin et al., 2015). More specifically, smart city initiatives typically adopt a corporate vision of what it means to be 'smart' (Söderström et al., 2014): consistent with an entrepreneurial form of urban governance (Harvey, 1989), they prioritise the attraction of investment and the fostering of economic development over an agenda of social development and democratic enlivenment. When citizens are at all taken into consideration, they are required to be compliant and to act along the lines that have been designed for them rather than actively participate in the shaping of their city (Gabrys, 2014). It raises the following question: who are the 'smart people' that will inhabit NCC? 'Decongesting Manila' can indeed be interpreted as an opportunity for a select few to opt out from the national capital region in order to join a city that enjoys premium urban space. If smart cities are often qualified as utopias (Datta, 2015; Townsend, 2013), it is perhaps useful to remember here that utopias tend to be selective. By their very nature, they are experimentations (Marvin et al., 2018), and as such they involve a group that is dissociated from the rest of the population.

Preliminary - and ongoing - work on the evaluation of NCC's socio-spatial impact is certainly worrisome (Ortega et al., 2019), with the displacement of communities that had been cultivating the land in Clark for generations, notably the Aeta Hungey tribe (Philippine Inquirer, 2019). Given the unfinished state of NCC, one can only offer cautionary statements. The focus on service provision adopted in this article can, however, inform on the question of territorial inequalities and social inclusion/exclusion, as the following subsection will demonstrate.

\section{A state of infrastructural exception}

While we cannot assess the social diversity of a city that has yet to be fully built, we can analyse the unfolding of infrastructure development and draw a few conclusions. The reflex here is to invoke the now widely known concept of splintering urbanism (Graham and Marvin, 2001), which precisely describes a process of widening socio-spatial inequalities resulting from increasing disparities in infrastructure provision. Graham and Marvin argue that the liberalisation of service provision in numerous countries - combined with inter-city competition - has led to the collapse of a modern ideal of universal and homogenous service provision. Instead, profit-driven service providers are now increasingly differentiating their offers, bypassing poorer, less financially appealing areas while focusing their resources towards premium spaces where more affluent urbanites can afford to pay more for better quality. The narrative is appealing in the context of the Philippines and its adoption of policies that led to the privatisation of large technical networks (water, telecommunications, electricity) in the 1990s (Bello, 2005). The story is, however, not so straightforward.

In terms of infrastructure provision, NCC's story is indeed one of secession from the surrounding territory. It is true of the features that make it smart and environmentally friendly (e.g. district cooling, smart grids) and that, by definition, do not exist elsewhere - the rationale for such projects is precisely to explore these new technologies. But it is also true of more traditional urban services: electricity provision, water distribution and wastewater treatment. However, even if the conclusion corroborates Graham and Marvin's work, this process of fragmentation has less to do with the global trend of liberalisation, and more to do with the particularities of NCC. While the area would normally be within the franchise of a utility, it 
qualifies as a special economic zone - as do all projects undertaken by the BCDA. As such, NCC is withdrawn from utilities' franchise, and service provision is put on tender: the quality of service as well as its cost for the end-user are therefore renegotiated, and distinct from what prevails in the surrounding areas. ${ }^{4}$ A consortium composed of the Philippines' largest power utility, Meralco, and several Japanese firms (Marubeni Corp., The Kansai Electric Power Co. Inc. and Chubu Electric Power Co. Inc.) was selected out of four bidders for electricity distribution (Philippine Daily Inquirer, 2019). For water distribution and wastewater management, the BCDA selected a consortium led by the Philippine company PrimeWater and Israel's Tahal Group, out of three bidders (Business World, 2018). Once again, such elements point to the need to situate the analysis, and consider the interplay between local contingencies and global macroeconomic forces. The case of NCC therefore adds to previous critiques of splintering urbanism's main idea (Coutard, 2002, 2008) - not least critiques that emerged from the study of cities in the global South (Jaglin, 2008; Zérah, 2008), where the existence of a modern ideal needs to be questioned more critically, as does the assumption of a convergence with a Western model of service provision.

Regardless of the process, the smart city's infrastructure is practically disconnected from the surrounding territories. This raises questions in terms of socio-spatial solidarities, given that a now well-established scholarly tradition has envisioned large technical networks as a factor of cohesion - materially, socially and economically (Coutard and Rutherford, 2015; Tarr and Dupuy, 1988). If the more prosperous areas are isolated from the rest of Luzon - the Philippines' largest island - it calls the techno-economic model of urban services into question.

\section{'Worlding infrastructure': NCC between regional influences and local balance of power}

In the previous section, I made a case for considering smart cities as infrastructure in order to better understand the actors behind their production, the objectives they set, as well as their socio-spatial consequences, intended or not. With this section, I seek to come back to the initial research question and investigate the heuristic value of such an approach with regards to the literature on worlding cities. More specifically, this article represents an attempt to follow the STS tradition, and integrate it with the literature on worlding efforts in cities of the global South. While this concept has enjoyed considerable attention in the field of urban studies, few attempts have been made to explore its relevance for the study of infrastructure provision. The term 'worlding' has recently been mobilised by Furlong and Kooy (2017), but the focus here was placed on provincialising the question of water provision, and less attention was placed on actors' strategies to produce or adopt 'urban norms that count as "global"' (Roy and Ong, 2011: 2).

The concept of worlding 'serves as a counterpoint to the framework of global/ world cities that has become commonplace in urban theory', and represents an attempt to 'recover and restore the vast array of global strategies that are being staged at the urban scale around the world' (Roy, 2011: 9-10). Through new practices of modelling, inter-referencing and association, the concept points to new geographies in the production of urban imaginaries - geographies that extend well beyond the handful of Western cities that scholars have traditionally used as a template in order to gauge and characterise urban change elsewhere. Roy and Ong (2011) convincingly show how regional models have emerged in Asia (e.g. Singapore, 
Table I. List of companies with which the BCDA signed a memorandum of understanding for the construction of NCC.

\begin{tabular}{|c|c|c|}
\hline Company & Headquarters & Role in NCC \\
\hline AECOM & United States & Master plan for NCC \\
\hline $\begin{array}{l}\text { Surbana Jurong } \\
\text { Nippon Koei }\end{array}$ & $\begin{array}{l}\text { Singapore } \\
\text { Japan }\end{array}$ & $\begin{array}{l}\text { Support for the master plan: development management } \\
\text { framework, standards guidelines and environmental } \\
\text { guidelines; integration of infrastructure and utilities } \\
\text { (power, water, sewerage, ICTs, security and traffic } \\
\text { management) }\end{array}$ \\
\hline $\begin{array}{l}\text { Hitachi Asia Ltd } \\
\text { The Power Grid } \\
\text { Solution Ltd }\end{array}$ & $\begin{array}{l}\text { Japan } \\
\text { Japan }\end{array}$ & $\begin{array}{l}\text { Energy management and storage system, district } \\
\text { cooling system, power distribution }\end{array}$ \\
\hline $\begin{array}{l}\text { KEPCO Philippines } \\
\text { Corporation (KEPHILCO) }\end{array}$ & South Korea & Energy management system in New Clark City \\
\hline MTD Capital & Malaysia & $\begin{array}{l}\text { Sports facilities for the Southeast Asian Games, } \\
\text { National government complex, integrated Operations } \\
\text { Center and Disaster Risk and Recovery Center }\end{array}$ \\
\hline
\end{tabular}

Source: BCDA http://www.bcda.gov.ph/ (last accessed I September 2018).

Hong Kong, Shanghai) and replaced more traditionally established, Western cities, as a point in reference. I would like to argue here that this trend is reflected in this Philippine project for a smart city, but that a second value of this grid of analysis is to emphasise that worlding strategies are situated.

\section{Aiming for a 'world-class' city}

'We are building a city that's like Singapore. They [Singapore] are a city in a garden. We say that we are a city in a farm.' This reference to Singapore came out quite unexpectedly in the course of an interview with an executive from the BCDA, as he was presenting the then-embryonic project of a smart city in Clark. ${ }^{5}$ In fact, this interview underlined that the organisation spearheading the development of NCC was resolutely looking at a number of other cities in order to set its own standards for urban development in the Philippines. The same person later went on and insisted:

We go out of the country to understand how things are done, to understand how roads are structured and built, how the utilities are built. So what we do when we go out of the country, we go to the museums where you can see their plans, and we even jog or walk around the city, looking at all the details: the pavement, if it's made of concrete, or with pebbles, or blocks. The trees, what kind of trees ... We interact with the community, with the environment. You do not learn these things just looking at PowerPoint slides. ${ }^{6}$

This approach translates into the training of BCDA employees: over 100 of them had recently been sent to Singapore for a field study and training, at the time of this interview. It also translates into the management of its development projects: the organisation multiplies partnerships with foreign companies, and conducts active outreach for expertise outside of the Philippines. In NCC, this is particularly striking given its goal of suffusing the urban fabric with highly advanced technologies. Therefore, while the core of NCC is to be developed by a Philippine company, Filinvest (see next subsection), a wide array of foreign partners is involved as well, in different capacities (see Table 1). The 
master plan is designed by the Los Angelesbased engineering firm AECOM, with input from a Japanese firm (Nippon Koei, as well as its Philippine subsidiary Philkoei International Inc.) and a Singaporean consulting firm (Suburbana Jurong). Energy questions in the area will also benefit from the expertise of Japanese and Korean companies: Hitachi Asia Ltd and its subsidiary The Power Grid Solution Ltd, plus KEPCO Philippines Corp. Other components of NCC are handled by firms belonging to the Malaysian conglomerate MTD Capital Berhad.

These elements echo the core ideas developed in Worlding Cities. The NCC project makes heavy use of the rhetoric used globally for the branding of cities: it is envisioned to be 'smart', 'green' and 'sustainable', but also 'liveable', and more generally 'world class'. The city of Singapore appears to be an inspiring model for the BCDA. ${ }^{7}$ The agency's previous project, Bonifacio Global City (the development of 214 hectares in Metro Manila), was also extensively marketed as a 'Philippine Singapore' (Shatkin, 2011) and driven by a desire to showcase Manila as a modern city (Garrido, 2013). The quote reproduced earlier in this article underlines that executives in charge of developing NCC seek to replicate the experience and urban feel that emanate from the cities they take as exemplars. Meanwhile, the multiplicity of partnerships with foreign companies can be understood as a form of interreferencing. These partnerships benefited from heavy advertisement through press releases and government channels (official websites and social media accounts). They are in fact highlighted by the BCDA's CEO Vince Dizon (CNN Philippines, 2017):

This could be the benchmark for cities in the country. We're benchmarking this city with cities like Incheon in South Korea, Songdo in South Korea, Suzhou in China, Tianjin in
China, Yokohama in Japan, and this is why to get the best we have to work with the best and this is why we partnered with Japan overseas network for infrastructure development, and with other premier master planners like Aecon.

Their role is to provide evidence that NCC benefits from the latest technologies and innovations in service provision and other smart infrastructure. The fact that most of the foreign companies involved in the partnerships are headquartered in the Asian continent echoes Roy and Ong's (2011) argument on the rise of a South-South circulation of models and expertise. In fact, the observation can be extended if one considers the financing of the project: the China Development Bank recently signed a memorandum of understanding with the BCDA to explore 'the most cost effective and efficient financing option for BCDA's projects in Clark and Metro Manila', and to involve Chinese companies in the 'investments, feasibility studies, independent consultancies, detailed engineering design, equipment procurement and construction' of the project (BCDA, 2018). Of note, the plethora of actors involved, however, raises questions with regards to the integrated nature of the different systems involved in the management of the city. This Frankenstein urbanism, as Cugurullo (2018) describes it, constitutes a point of tension between the hubris of controlling a centralised system that encompasses all aspects of urban life on the one hand, and the diversity of technologies, data formats and management tools that are expected to ensue from this multiplicity of stakeholders.

\section{A situated political economy}

As argued, NCC is a largely decontextualised urban product. It is a smart city that borrows features from a number of projects in Asia and in the world, and seeks to 
replicate successes achieved in a number of 'model' cities in terms of liveability, environmental and business friendliness, as well as legibility and governability through ICTs. Visually, the digital renderings created by the developers involved do not show a Philippine specificity. It looks as if smart city initiatives are invariant with respect to translational motion: the same urban landscape could very well find its place in Singapore or in Toronto. Does it mean that all of these projects are more or less the same, and that they are therefore hardly worth studying? Here, I would like to argue that attention should be paid not only to the project itself, but also to how it is developed - by whom, using whose funds, for the benefit of whom, etc. In other words, while the end-product is standardised, the process of its production is highly dependent on local contingencies, and has a lot to tell us about the Philippine political economy.

Here, the notion of worlding cities is still relevant, because it emphasises the situated nature of worlding practices. As Shatkin (2011: 93) argues, this strand of literature is not so much focused on evaluating the replication of urban models as it is interested in how these references are mobilised in local contexts:

the inter-referencing of Asian models, rather than reflecting a naive belief that cities can simply follow along the path beaten by other globalizing cities, instead reflects the shrewd employment of certain images and ideals to promote a very specific development agenda. [...] The referencing of Singapore, Shanghai, and other models provides design and governance templates that indicate the possibility of success, and therefore soften political and social opposition to these changes. The relevant question is therefore not whether this inter-referencing will 'work' (e.g., lead to the replication of urban outcomes), but rather how the models that result respond to local opportunities and constraints, how effective they are in overcoming obstacles to urban redevelopment, and what implications the resulting models of urban governance and design have for social and political change.

Looking more closely, the unfolding of NCC's development tells a story that is deeply rooted in the Philippine context. Its location, first, is noteworthy. Finding such a large tract of land - nearly 10,000 hectares is not an easy endeavour in the vicinity of Metro Manila. Its existence is intertwined with the national history: it was a former US military base that was only recovered by the country in 1991, when the Philippines decided not to renew its agreement with the USA. The organisation spearheading the development of the city is therefore quite unique: the BCDA was created a year after, in 1992 (Republic Act 7227), in order to manage the sizeable land-bank recovered by the state (of which the Clark military base is only a portion), and transform it into industrial and real-estate developments. The BCDA answers directly to the office of the president, and has extensive powers over its land-bank (including the power of eminent domain) but also beyond, since it is able to own, lease, operate and maintain public infrastructures and utility facilities. It is currently a central actor in the efforts of the Philippine state to reassert control over the urbanisation of the Mega-Manila region (Mouton and Shatkin, 2019).

Second, the way the BCDA operates is distinctive and reflects the landscape of actors involved in urban production in the Philippines. It defines the specification for the land development project, and puts it on tender. It then selects a partner among the applicants, with which it forms a joint venture: the private partner holds $55 \%$ of the shares, while the BCDA keeps the other $45 \%$. This peculiar form of PPP gives the state agency better control over its project, and is well-aligned with the government's 
current ambition to harness the activity of developers and become more directive in the planning of the wider metropolitan region of Manila:

[PPPs] have been the most successful model for us. [...] [The corporation we form] has become a private entity, but at the same time, with our $45 \%$ equity, we get to see how the development unfolds, and how the decisionmaking process is done. So we have a vetting process, we have a vetting authority on this corporation. $^{8}$

Partnering with private companies was a necessity for the public agency, which had land but virtually no budget at its inception. ${ }^{9}$ Clark therefore operates on a forprofit basis: the BCDA provides the land, and developers finance the construction and recover their investment by leasing the properties. The formula holds for the public components of the project: the government agencies seeking to relocate to the National Government Administrative Centre are encouraged to obtain financing options from a local bank for the leasing or acquisition of office buildings, under the umbrella of an agreement negotiated by the BCDA, MTD Clark Inc. (the developer of the administrative centre) and the Land Bank of the Philippines Leasing and Finance Corporation (Sunstar, 2019).

The successful candidate for the development of NCC's core element is well-known: it is Filinvest Land Inc., a subsidiary of Filinvest Development Corp. The country is characterised by the prominence of a small number of family-owned conglomerates that dominate the national economy in general, and real estate in particular (Hutchcroft, 1991). There is, consequently, a small number of powerful land developers who have the capacity to design and build entire portions of the city, largely in autonomy from public authorities' own plans (Lorrain and Mouton, 2017; Shatkin, 2008, 2017; Van den Muijzenberg and Van Naerssen, 2005). Filinvest is one of them. The conglomerate is diversified into banking ( $42 \%$ of $2017 \mathrm{rev}$ enues), real estate $(40 \%)$, power generation and retail $(15 \%)$ and sugar $(3 \%)$ (Filinvest Development Corporation, 2017: 8). Its realestate presence includes residences, office buildings as well as shopping centres, leisure and tourism-oriented buildings - these activities generating 26.8 billion pesos (over US\$510 million) of revenues in 2017 (Filinvest Development Corporation, 2017: 9). In Metro Manila, it is best known for its Filinvest City, a 244-hectare, mixed-use, integrated complex in the southern part of the national capital region. Of note, the group also won the bid for the privatisation of a 202-hectare tourism complex, the Mimosa Leisure Estate, located in the Clark Special Economic Zone - managed by the Clark Development Corp., an arm of the BCDA. The property is located next to Clark International Airport, and comprises a hotel (with three more being planned), 100 villas and two golf courses (Philippine Star, 2016). The developer has been awarded a provisional licence for the construction of a casino, around which the estate will be integrated.

This operation considerably consolidates Filinvest's presence in Clark. The story, however, also involves newer actors. While Filinvest is an established player in this country-wide game of Monopoly, the development of Clark also opened opportunities for new contenders. Udenna Corporation is one of them. Its CEO, Dennis Uy, is close to President Duterte. A fellow Davaoeño, Uy supported Rodrigo Duterte in the presidential race, with a 30-million pesos contribution to his campaign (Rappler, 2018a). In turn, Rodrigo Duterte has shown support to the rising tycoon, frequently inviting him as a private-sector delegate during foreign visits and attending the 10th listing anniversary of Phoenix Petroleum, a subsidiary of Udenna 
(Rappler, 2017b). Udenna acquired 177 hectares of land within the Clark Freeport Zone - land adjacent to the Clark Special Economic Zone. Its plans involve office space, retail (with a mall occupying a 10-hectare plot of land, developed by leader in the sector SM Corp.; Rappler, 2018b), luxury hotels, residential space and, finally, the promise of an 'iconic tower' envisioned to 'rival the Macau tower and Paris' Eiffel Tower' (Rappler, 2018a). Udenna's investment totals US\$5 million over 10 years (Business Mirror, 2018).

NCC can therefore be understood as the result of an alignment between the agenda of a state willing to decongest Metro Manila and 'show off' with top-notch infrastructure, and that of private corporations seeking to extend their presence in the north of the capital region in order to constitute an entire territory where they can create synergies between different urban functions.

\section{Conclusion}

In line with the framing of this special issue on smart cities, this article pursued the objective of analysing NCC through the lens of the literature around worlding practices in cities of the global South. In order to do so, I first argued for the recognition of the materiality of smart city initiatives: they may very well be compared to other types of entrepreneurial and profit-driven real-estate projects, but they retain a specificity in that they involve complex and sophisticated infrastructure. This feature is not without significance when one considers the place of service delivery in the Philippine political debate. Urbanites' lives are routinely affected by defective or inadequate infrastructure, and development agencies and consultancy firms lament the inefficiencies this causes. Politically, bringing forward a smart city initiative that promises a smooth and efficient experience of the urban setting for its urbanites is therefore rewarding. It also contributes to urban elites' efforts to create 'world-class' spaces. Here, the strategy of inter-referencing evinced by Roy and Ong (2011) is of particular relevance. By making references to other cities and multiplying partnerships with foreign companies, the BCDA is effectively marketing NCC as a 'global' space that benefits from the latest and most advanced technologies available worldwide. However, this strategy is embedded within local forms and practices of urban production, which are negotiated by local actors.

By examining this smart city initiative's infrastructure plans, this article sought to complement a Worlding Cities literature that mostly focuses on the visible part of the built environment. The last section shows, in this regard, that such an approach can fuel the debate over the social inclusion - or lack thereof - of worlding projects. It indeed shows that public authorities have privileged the creation of an independent, disconnected system of service provision. The logic here is not to improve the quality and reliability of urban services throughout the country, but rather to create a zone of exception, which will cater for the needs of a lucky few.

\section{Acknowledgements}

I would like to thank the anonymous reviewers, as well as the special issue's guest editors, for their comments and insights. I also learned a lot in the course of my discussions with Gavin Shatkin, Dominique Lorrain, Alvaro Artigas and Sylvy Jaglin.

\section{Declaration of conflicting interests}

The author(s) declared no potential conflicts of interest with respect to the research, authorship, and/or publication of this article.

\section{Funding}

The author(s) disclosed receipt of the following financial support for the research, authorship, 
and/or publication of this article: Fieldwork for this work was funded by Universite Paris-Est. When writing the article, I also benefited from the support of University of Calgary's O'Brien Institute for Public Health and Cumming School of Medicine, as well as Canada's Social Sciences and Humanities Research Council.

\section{ORCID iD}

Morgan Mouton (iD https://orcid.org/0000-00023324-4808

\section{Note}

1. Original translation from the press article.

2. The list is available on a dedicated website: http://build.gov.ph/ (last accessed 30 August 2018).

3. Interview with executives from the BCDA and its subsidiary, Bonifacio Estates Services Corp. (Taguig City, May 2016).

4. Interview with an executive from Bonifacio Estates Services Corporation (Taguig City, May 2016).

5. Interview with an executive from the BCDA (Taguig, May 2016).

6. Interview with an executive from the BCDA (Taguig, May 2016).

7. It is noteworthy here that the BCDA seeks to follow the path of a city whose strategy has been to aggressively attract foreign capital, which has translated into the heavy presence of multi-national corporations in the stateisland (see Huff, 1997).

8. Interview with an executive from the BCDA (Taguig, May 2016).

9. Interview with an executive from the BCDA (Taguig, May 2016).

\section{References}

ADB (2013) Asian development outlook 2013: Governance and public service delivery. Available at: http://wedocs.unep.org/handle/20.500. 11822/8898 (accessed 4 December 2019).

Alegado S (2018) Duterte's $\$ 180$ billion building boom may be expats' ticket home. Bloomberg Businessweek, 23 January. Available at: https: //www.bloomberg.com/news/articles/2018-0123/duterte-s-180-billion-building-boom-may- be-expats-ticket-home (accessed 4 December 2019).

BCDA (2018) DBP Grants Php9.5 Billion Loan To AlloyMTD for Construction of Government Center in New Clark City. Taguig: BCDA.

Bello W (2005) The Anti-Development State: The Political Economy of Permanent Crisis in the Philippines. London: Zed Books.

Boquet Y (2013) Battling congestion in Manila: The EDSA problem. Transport and Communications Bulletin for Asia and the Pacific 82: 45-59.

Business Insider (2018) The Philippines is planning a $\$ 14$ billion 'pollution-free' city that will be larger than Manhattan. Available at: https://www.independent.co.uk/news/world/ philippines-new-city-bigger-manhattan-newclark-sustainable-14-billion-a8347281.html (accessed 4 December 2019).

Business Mirror (2018) Udenna Group to spend $\$ 5$ billion to develop Clark Global City. Available at: https://businessmirror.com.ph/2018/ 05/29/udenna-group-to-spend-5-billion-to-deve lop-clark-global-city/ (accessed 4 December 2019).

Business World (2018) BCDA, Villar-led consortium ink water deal for New Clark City. Available at: https://www.bworldonline.com/ bcda-villar-led-consortium-ink-water-deal-fornew-clark-city/ (accessed 4 December 2019).

Caoili MA (1989) The Origins of Metropolitan Manila: A Political and Social Analysis. Quezon City: Cellar Book Shop.

CNN Philippines (2017) New Clark City to become 'symbol of modern Philippines'. Available at: http://nine.cnnphilippines.com/ videos/2017/11/28/New-Clark-City-to-becomeSymbol-of-Modern-Philippines-BCDA-Pres.. html (accessed 4 December 2019).

Coutard O (2002) 'Premium networked spaces': A comment. International Journal of Urban and Regional Research 26: 166-174.

Coutard O (2008) Placing splintering urbanism: Introduction. Geoforum 39: 1815-1820.

Coutard O and Guy S (2007) STS and the city: Politics and practices of hope. Science, Technology \& Human Values 32: 713-734.

Coutard O and Rutherford J (2015) Beyond the Networked City: Infrastructure Reconfigurations and Urban Change in the North and South. London and New York: Routledge. 
Cugurullo F (2018) Exposing smart cities and eco-cities: Frankenstein urbanism and the sustainability challenges of the experimental city. Environment and Planning A: Economy and Space 50: 73-92.

Datta A (2015) New urban utopias of postcolonial India: 'Entrepreneurial urbanization' in Dholera smart city, Gujarat. Dialogues in Human Geography 5: 3-22.

Datta A (2016) Introduction: Fast cities in an urban age. In: Datta A and Shaban A (eds) Mega-Urbanization in the Global South. London: Routledge, pp. 13-40.

Datta A (2018) The digital turn in postcolonial urbanism: Smart citizenship in the making of India's 100 smart cities. Transactions of the Institute of British Geographers 43: 405-419.

Edwards P and Hecht G (2010) History and the technopolitics of identity: The case of apartheid South Africa. Journal of Southern African Studies 36: 619-639.

Filinvest Development Corporation Annual report. Taguig City: Filinvest.

Florida R (2004) The Rise of the Creative Class and How It's Transforming Work, Leisure, Community and Everyday Life. New York: Basic Books.

Forbes (2018) Duterte's ambitious 'build, build, build' project to transform the Philippines could become his legacy. Available at: https:// www.forbes.com/sites/outofasia/2018/02/28/ dutertes-ambitious-build-build-build-projectto-transform-the-philippines-could-becomehis-legacy/\#79b86bd61a7f (accessed 4 December 2019).

Furlong K and Kooy M (2017) Worlding water supply: Thinking beyond the network in Jakarta. International Journal of Urban and Regional Research 41: 888-903.

Gabrys J (2014) Programming environments: Environmentality and citizen sensing in the smart city. Environment and Planning D: Society and Space 32: 30-48.

Gandy M (2005) Cyborg urbanization: Complexity and monstrosity in the contemporary city. International Journal of Urban and Regional Research 29: 26-49.

Garrido M (2013) The ideology of the dual city: The modernist ethic in the corporate development of Makati city, Metro Manila.
International Journal of Urban and Regional Research 37: 165-185.

Graham S and Marvin S (2001) Splintering Urbanism: Networked Infrastructures, Technological Mobilities and the Urban Condition. London and New York: Routledge.

Harris A (2013) Concrete geographies. City 17: 343-360.

Harvey D (1989) From managerialism to entrepreneurialism: The transformation in urban governance in late capitalism. Geografiska Annaler. Series B. Human Geography 71: 3-17.

Hecht G (2014) Le rayonnement de la France. Paris: Éditions Amsterdam.

Hollands RG (2008) Will the real smart city please stand up? Intelligent, progressive or entrepreneurial? City 12: 303-320.

Hollands RG (2015) Critical interventions into the corporate smart city. Cambridge Journal of Regions, Economy and Society 8: 61-77.

Huff WG (1997) The Economic Growth of Singapore: Trade and Development in the Twentieth Century. Cambridge: Cambridge University Press.

Human Rights Watch (2018) Philippines: Events of 2017. World report 2018. Available at: https://www.hrw.org/world-report/2018/coun try-chapters/philippines (accessed 4 December 2019).

Hutchcroft P (1991) Oligarchs and cronies in the Philippine state: The politics of patrimonial plunder. World Politics 43: 414-450.

Jaglin S (2008) Differentiating networked services in Cape Town: Echoes of splintering urbanism? Geoforum 39: 1897-1906.

Jaglin S and Dubresson A (2016) Eskom: Electricity and Technopolitics in South Africa. Cape Town: UCT Press.

Kind HJ (2000) The Philippines - The sick man of Asia? Economic development in the Philippines after 1946. Foundation for Research in Economics and Business Administration Working Paper.

Kitchin R (2014) The real-time city? Big data and smart urbanism. GeoJournal 79: 1-14.

Larkin B (2013) The politics and poetics of infrastructure. Annual Review of Anthropology 42: 327-343.

Le Galès P and Lorrain D (2003) Gouverner les très grandes métropoles? Revue française d'administration publique 107: 305-317. 
Lorrain D (2014) Governing Megacities in Emerging Countries. Farnham: Ashgate Publishing.

Lorrain D and Mouton M (2017) Conglomérats familiaux et infrastructures essentielles. Le cas des Philippines. In: Chatzis K, Jeannot G, November V, et al. (eds) Les métamorphoses des infrastructures, entre béton et numérique. Brussels: Peter Lang, pp. 123-144.

McFarlane C (2010) Infrastructure, interruption, and inequality: Urban life in the Global South. In: Graham S (ed.) Disrupted Cities: When Infrastructure Fails. New York: Routledge, pp. 131-143.

McFarlane C and Rutherford J (2008) Political infrastructures: Governing and experiencing the fabric of the city. International Journal of Urban and Regional Research 32: 363-374.

Marshall T (2012) Planning Major Infrastructure: A Critical Analysis. London: Routledge.

Marvin S, Bulkeley H, Mai L, et al. (2018) Urban Living Labs: Experimenting with City Futures. London: Routledge.

Marvin S, Luque-Ayala A and McFarlane C (2015) Smart Urbanism: Utopian Vision or False Dawn? London: Routledge.

Mouton M (2015) The Philippine electricity sector reform and the urban question: How Metro Manila's utility is tackling urban poverty. Energy Policy 78: 225-234.

Mouton M and Shatkin G (2019) Strategizing the for-profit city: The state, developers, and urban production in Mega Manila. Environment and Planning A: Economy and Space. Published online 2 April. DOI: 10.1177/ $0308518 X 19840365$.

Navarro AM (2016) Scrutinising urbanisation challenges in the Philippines through the infrastructure lens. In: Lye LF and Wong $\mathbf{J}$ (eds) The Challenge of Making Cities Liveable in East Asia. Singapore: World Scientific, pp. 45-63.

Ortega AA, Lopez Y and Martinez O (2019) Counter-mapping for urban social justice dispossession, resistance and spaces of hope. In: Centre for Sustainable, Healthy and Learning Cities and Neighbourhoods Seminar. 1 May 2019. University of Glasgow, UK.

Philippine Daily Inquirer (2019) Meralco, Japanese venture to power New Clark City. Available at: https://business.inquirer.net/268079/ meralco-japanese-venture-to-power-new-clarkcity (accessed 4 December 2019).

Philippine Inquirer (2019) New Clark City: Development for whom? Available at: https://news info.inquirer.net/1139364/new-clark-city-devel opment-for-whom (accessed 4 December 2019).

Philippine Star (2015) Metro Manila traffic costing Philippines P3 billion a day. Available at: https://www.philstar.com/headlines/2015/09/1 6/1500512/metro-manila-traffic-costing-philip pines-p3-billion-day (accessed 4 December 2019).

Philippine Star (2016) Filinvest to take over Mimosa Clark. Available at: https://www. philstar.com/business/2016/04/25/1576671/fili nvest-take-over-mimosa-clark (accessed 4 December 2019).

Picon A (2015) Smart Cities: A Spatialised Intelligence. Chichester: John Wiley \& Sons.

Picon A (2017) Infrastructures et imaginaire. Une lecture alternative du changement technique. In: Chatzis $\mathrm{K}$, Jeannot $\mathrm{G}$, November $\mathrm{V}$, et al. (eds) Le Nouveau monde des infrastructures. Brussels: Peter Lang, pp. 51-66.

Picon A (2018) Urban infrastructure, imagination and politics: From the networked metropolis to the smart city. International Journal of Urban and Regional Research 42: 263-275.

Porio E (2014) Climate change vulnerability and adaptation in Metro Manila. Asian Journal of Social Science 42: 75-102.

Pritchard S (2011) Confluence: The Nature of Technology and the Remaking of the Rhone. Boston, MA: Harvard University Press.

Rappler (2017a) Duterte: Manila will be a 'dead city' in 25 years. Available at: rappler.com/ nation/190698-duterte-manila-dead-city-decen tralization-philippines (accessed 4 December 2019).

Rappler (2017b) How to grow a business, according to Dennis Uy. Available at: https://www. rappler.com/business/175419-dennis-uy-davao -tycoon-duterte-connection (accessed 4 December 2019).

Rappler (2018a) Dennis Uy to bring BGC to Pampanga. Available at: https://www.rap pler.com/business/203628-dennis-uy-udennaclark-global-city-pampanga (accessed 4 December 2019). 
Rappler (2018b) SM to expand in Clark Global City. Available at: https://www.bworldonline. com/sm-to-expand-in-clark-global-city/ (accessed 4 December 2019).

Rowland N and Passoth J-H (2015) Infrastructure and the state in science and technology studies. Social Studies of Science 45: 137-145.

Roy A (2011) Urbanisms, worlding practices and the theory of planning. Planning Theory 10: 6-15.

Roy A and Ong A (2011) Worlding Cities: Asian Experiments and the Art of Being Global. Chichester and Malden, MA: Wiley-Blackwell.

Shatkin G (2008) The city and the bottom line: Urban megaprojects and the privatization of planning in Southeast Asia. Environment and Planning A 40: 383-401.

Shatkin G (2011) Planning privatopolis: Representation and contestation in the development of urban integrated mega-projects. In: Roy A and Ong A (eds) Worlding Cities: Asian Experiments and the Art of Being Global. Malden, MA: Blackwell Publishing, pp. 77-97.

Shatkin G (2017) Cities for Profit: The Real Estate Turn in Asia's Urban Politics. Ithaca, NY: Cornell University Press.

Shelton T, Zook M and Wiig A (2015) The 'actually existing smart city'. Cambridge Journal of Regions, Economy and Society 8: 13-25.

Silver J (2016) Disrupted infrastructures: An urban political ecology of interrupted electricity in Accra. International Journal of Urban and Regional Research 39: 984-1003.

Söderström O, Paasche T and Klauser F (2014) Smart cities as corporate storytelling. City 18: 307-320.
Sunstar (2019) BCDA, partners offer funding options to NCC locators. Available at: https://www.sunstar.com.ph/article/1817711 (accessed 4 December 2019).

Tarr JA and Dupuy G (1988) Technology and the Rise of the Networked City in Europe and America. Philadelphia, PA: Temple University Press.

Townsend AM (2013) Smart Cities: Big Data, Civic Hackers, and the Quest for a New Utopia. New York: W.W. Norton.

Van den Muijzenberg $\mathrm{O}$ and Van Naerssen $\mathrm{T}$ (2005) Metro Manila: Designers or directors of urban development? In: Nas PJM (ed.) Directors of Urban Change in Asia. London: Routledge, pp. 126-147.

Vanolo A (2014) Smartmentality: The smart city as disciplinary strategy. Urban Studies 51(5): 883-898.

Watson V (2014) African urban fantasies: Dreams or nightmares? Environment and Urbanization 26: 215-231.

Wiig A (2015) IBM's smart city as techno-utopian policy mobility. City 19: 258-273.

World Bank (2005) Philippines: Meeting Infrastructure Challenges. Washington, DC: World Bank.

World Bank (2010) Public-Private Partnerships for Urban Water Utilities: A Review of Experiences in Developing Countries. Washington, DC: World Bank.

Zérah M-H (2008) Splintering urbanism in Mumbai: Contrasting trends in a multilayered society. Geoforum 39: 1922-1932. 